\title{
Pengaruh Kepemimpinan, Motivasi dan Religiusitas Terhadap Kepuasan Kerja Karyawan pada PT. Unza Vitalis Salatiga
}

\author{
Ahmad Baihaqi \\ Program Studi Perbankan Syariah (S1) STAIN Salatiga \\ Email:ahmad_baihaqi94@yahoo.com
}

\begin{abstract}
The study examined the influence of leadership, motivation and religiosity on job satisfaction at. Unza Vitalis Salatiga. Regression model of this quantitative research is: $\mathrm{Y}=-44.504+0.290 \mathrm{~K}+\mathrm{M}+0,270 \mathrm{R} 1,070$. The research concluded that leadership, motivation, and religiosity positive and significant impact on job satisfaction of employees of PT. Unza Vitalis Salatiga. Leadership, motivation and religiosity simultaneously affect job satisfaction with the positive and significant at PT. Unza Vitalis Salatiga. The most dominant variable in influencing job satisfaction is work motivation.
\end{abstract}

Keywords: leadership, motivation and religiosity, job satisfaction

\begin{abstract}
Abstrak
Studi ini meneliti pengaruh kepemimpinan, motivasi kerja dan religiusitas terhadap kepuasan kerja pada PT. Unza Vitalis Salatiga. Model persamaan regresi dari penelitian kuantitatif ini adalah: $\mathrm{Y}=-44,504+0,290 \mathrm{~K}+1,070$ $\mathrm{M}+0,270 \mathrm{R}$

Berdasarkan penelitian disimpulkan bahwa kepemimpinan, motivasi kerja, dan religiusitas berpengaruh positif dan signifikan terhadap kepuasan kerja karyawan PT. Unza Vitalis Salatiga. Kepemimpinan, motivasi kerja dan religiusitas secara simultan mempengaruhi kepuasan kerja dengan positif dan signifikan pada PT. Unza Vitalis Salatiga. Variabel paling dominan dalam mempengaruhi kepuasan kerja adalah motivasi kerja.
\end{abstract}

Kata kunci: kepemimpinan, motivasi kerja dan religiusitas, kepuasan kerja 


\section{Pendahuluan}

Undang-Undang No. 3 Tahun 1982 perusahaan didefinisikan sebagai bentuk usaha yang menjalankan setiap jenis usaha yang bersifat tetap dan terus menerus dan yang didirikan, bekerja serta berkedudukan dalam wilayah Negara Republik Indonesia, untuk tujuan memperoleh keuntungan dan atau laba.Banyak para ahli mendefinisikan pengertian perusahaan namun intinya setiap perusahaan mempunyai tujuan yang sama, yaitu memperoleh dan memaksimalkan laba. Dalam pencapaian tujuan, perusahaan memerlukan keunggulan kompetitif dan komperatif yang dikelola secara efektif, efisien, baik dan excellent. Dengan begitu dapat dikatakan perusahaan memerlukan seorang pemimpin yang dapat melaksanakan fungsi kepemimpinan untuk mencapai tujuan perusahaan.

Dalam bahasan teori dan perilaku organisasi Siswanto dan Sucipto (2008: 196) menyatakan terdapat kelompok pakar yang memandang bahwa kepemimpinan merupakan hasil dari kualitas individu dan hanya dimiliki orang-orang tertentu. Kelompok pakar lainya mengatakan bahwa kepemimpinan tergantung pada faktor followership dan sebagian lainya lagi mengatakan kepemimpinan merupakan state of mind (konstruk sosial dan psikologis imajiner). Hal ini menjadikan kepemimpinan sebagai topik yang menarik untuk diteliti. Terlebih jika melihat kondisi kepemimpinan di Indonesia yang menimbulkan perbedaan persepsi dan mengingat pentingnya kedudukan pemimpin dalam sautu perusahaan atau instansi, terkait dengan keberbasilan dalam pencapaian visi, misi dan tujuan perusahaan atau instansi yang bersangkutan. Pentingnya peran pemimpin dalam menentukan keberhasilan organisasi dikuatkan lagi dengan pernyataan (Robbins dan Judge, 2005: 49) bahwa kepemimpinan (leadership) merupakan kemampuan untuk memengaruhi suatu kelompok guna mencapai sebuah visi atau serangkaian tujuan yang ditetapkan.

Tugas utama seorang pemimpin harus dapat menciptakan situasi kerja yang kondusif, mengelola dan memberdayakan karyawan sehingga para karyawan dapat melaksanakan tugas dengan baik, kemampuan dan prestasi kerja meningkat.

Motivasi diyakini dapat meningkatkan kinerja karyawan, dalam hal 
ini seorang manajer perlu mengarahkan motivasi dengan menciptakan kondisi (iklim) organisasi melalui pembentukan budaya kerja atau budaya organisasi sehingga para karyawan merasa terpacu untuk bekerja lebih keras agar kinerja yang dicapai juga tinggi (Ermayanti, 2001: 3 dalam Brahmasari dan Suprayitno, 2008: 125). Perbedaan motivasi dari setiap karyawan, membuat seorang pemimpin perlu mengarahkan motivasi dari karyawan kearah tujuan organisasi, sehingga pimpinan dapat memberikan motivasi kepada karyawan secara efektif dan efisien.

Wibowo (2007: 379) menyimpulkan bahwa motivasi merupakan dorongan terhadap serangkaian proses perilaku manusia pada pencapaian tujuan, yang didalamnya terdapat elemen-elemen yang membangkitkan, mengarahkan, menjaga, menunjukkan, intensitas, bersifat continue dan bertujuan.

Keberagamaan atau religiusitas menuntut penganutnya untuk mendalami ajarannya, memperkuat keyakinan dan melaksanakan perintah dengan kaidah-kaidah yang berlaku serta menjauhi larangan yang ada dalam ajarannya. Dalam bahasan Sulistyo (2011: 255) terdapat kelompok penelitian yang menemukan pengaruh positif religiusitas dengan sikap terhadap kerja (McClelland, 1961; Simmons, 2005; Weaver \& Agle, 2002), sedangkan penelitian yang dilakukan Elci (2007) menyimpulkan bahwa tidak ada hubungan yang signifikan antara religiusitas dengan kebutuhan berprestasi maupun afiliasi, dan religiusitas berhubungan negatif dengan kebutuhan atas kekuasaan.

Kepuasan kerja (job satisfaction) merupakan sasaran penting bagi pihak manajemen perusahaan dalam mengelola sumber daya manusia kaitannya dengan kinerja dan produktivitas yang akan memaksimalkan laba. Menurut Martoyo (2000, dalam Nalendra, 2008: 2), kepuasan kerja merupakan keadaan emosional karyawan yang terjadi maupun tidak terjadi yang merupakan titik temu antara nilai balas jasa atas suatu pekerjaan dengan tingkat nilai balas jasa yang memang diinginkan oleh karyawan. Raharjo dan Nafisah (2006: 71) menerangkan bahwa kepuasan kerja merupakan konsep praktis yang sangat penting dan merupakan hasil dari keefektifan performance dan kesuksesan pekerjaan.

Dari hal tersebut penulis mengasumsikan bila kepemimpinan, 
motivasi, budaya organisasi dan religiusitas berpengaruh terhadap kepuasan kerja karyawan. Untuk menjawab asumsi tersebut, maka peneliti mencoba melakukan penelitian pada PT. Unza Vitalis Salatiga Indonesia dengan judul "Pengaruh Kepemimpinan, Motivasi Dan Religiusitas Terhadap Kepuasan Kerja Karyawan Pada Pt. Unza Vitalis Salatiga”.

\section{Kepemimpinan}

O'Hair, Friedrich dan Dixon (2009: 195), memaknai kepemimpinan sebagai sebuah proses mempengaruhi bawahan, atasan dan rekan untuk mencapai tujuan dengan menggunakan metode komunikasi strategi yang mencakup nilai, visi, identifikasi tujuan, orientasi ke depan, dan perilaku penting lainya yang membuat kita mampu beradaptasi dengan tantangan era reformasi. Dalam buku mereka juga diutarakan pendapat John F. Kennedy yang mengemukakan bahwa kepemimpinan dan proses belajar merupakan hal mutlak yang saling melengkapi.

Robbins dan Judge (2005: 49) mendefinisikan kepemimpinan (leadership) sebagai kemampuan untuk memengaruhi suatu kelompok guna mencapai sebuah visi atau serangkaian tujuan yang ditetapkan.

Dalam penelitian Siswanto dan Sucipto (2008: 195), diutarakan pendapat House dkk., (1999) yang menyatakan bahwa kepemimpinan merupakan suatu kemampuan individu untuk mempengaruhi, memotivasi dan memungkinkan pengikutnya untuk memberikan kontribusi terhadap efektifitas dan kesuksesan organisasi, sedangkan Richard \& Engle (1986) mendefinisikan kepemimpinan sebagai kemampuan untuk mengungkapkan visi, mewujudkan nilai dan membentuk lingkungan yang dapat dibentuk.

Buhler (2001: 327) mengatakan bahwa kepemimpinan merupakan menggunakan pengaruh untuk mengarahkan aktivitas dan sikap orang lain tanpa menggunakan kekerasan dan paksaan. As-Suwaidan dan Basyarahil (2005: 41) mengartikan kepemimpinan sebagai aktivitas menggerakkan orang lain untuk mencapai tujuan tertentu.

Dari definisi kepemimpinan di atas, dapat dilihat bahwa sebagian besar para ahli mendifinisikan kepemimpinan dalam makna yang berbeda- 
beda, namun mempunyai makna inti, yaitu suatu proses mempengaruhi atau menggerakkan. Dengan kata lain kepemimpinan merupakan kemampuan untuk memengaruhi dan menggerakkan bawahan atau anggota organisasi untuk mencapai visi atau tujuan yang telah ditetapkan suatu kelompok.

Gaya kepemimpinan merupakan cara yang disenangi dan digunakan pemimpin dalam melakukan tugas-tugasnya, yaitu mempengaruhi orang lain untuk mencapai tujuan organisasi. Gaya kepemimpinan tidak hanya sebatas yang ada pada penelitian di atas, namun terdapat banyak gaya kepemimpinan lain yang diutarakan oleh para ahli, berikut teori tentang gaya kepemimpinan dalam pendekatan kontemporer:

1. Gaya Kepemimpinan Transformasional dan Transaksional

Robbins dan Coulter (2005: 193) menjelaskan bahwa model kepemimpinan transformasional lebih cenderung memberikan inspirasi pengikutnya untuk bertindak melebihi kepentingan peribadi demi kepentingan organisasi dan menimbulkan dampak yang luar biasa pada pengikutnya. Model ini mengintegrasikan ide-ide yang dikembangkan dalam pendekatan watak, gaya, dan kontingensi.

Kedua penulis tersebut juga mengemukakan bahwa pemimpin transaksional merupakan pemimpin yang membimbing atau memotivasi pengikutnya menuju sasaran yang ditetapkan dengan memperjelas peran dan tugas-tugasnya. Kepemimpinan transformasional dibangun karena adanya kepemimpinan transaksional, dan menghasilkan tingkat usaha dan kinerja yang jauh lebih baik dari pendekatan transaksional.

2. Gaya Kepemimpinan Kharismatik dan Visioner

Kepemimpinan Kharismatik merupakan gaya kepemimpinan dengan sifat antusias, percaya diri yang mana kepribadian dan tindakanya dapat mempengaruhi orang lain berperilaku dengan cara tertentu (Robbins dan Coulter, 2005: 194).

Kedua penulis di atas juga menjelaskan tentang kepemimpinan visioner, merupakan kepemimpinan untuk menciptakan dan menegaskan suatu visi yang realistis, dapat dipercaya, dan mempunyai cita-cita masa depan yang menarik bagi organisasi yang dipimpin, serta dapat menumbuhkan keadaan sekarang ke arah yang lebih baik. 
3. Kepemimpinan Tim

Dalam bahasan menejemen, Robbins dan Coulter (2005: 198) mengutarakan empat fungsi kepemimpinan tim, yaitu sebagai penghubung dengan pihak luar, sebagai penyelesai masalah, menejer konflik dan berfungsi sebagai pembina.

Kepemimpinan memiliki kemiripan dengan menejemen, namun kepemimpinan tidak sama dengan menejemen, seperti pernyataan Robbins dan Judge (2008: 49) bahwa tidak semua pemimpin adalah menejer dan tidak semua menejer adalah pemimpin. Pemimpin berperan untuk mencapai efektifitas dan efisiensi serta mengarahkan dan memotivasi anggota organisasi agar mencapai visi misi. Sedangkan manajemen bertugas untuk merumuskan perencanaan, struktus organisasi beserta kerangka kerja dan melakukan pengawasan. Jadi keduanya dibutuhkan oleh sebuah organisasi atau perusahaan.

\section{Motivasi Kerja}

Motivasi muncul karena perlunya seseorang untuk memenuhi kebutuhan, namun dalam teori ekonomi menyatakan bahwa kebutuhan manusia tidak ada batasnya. Hal tersebut juga menjadikan motivasi sebagai topik yang hangat untuk diteliti. Dalam organisasi, motivasi sangat diperlukan sebagai salah satu cara untuk mencapai tujuan yang telah ditetapkan perusahaan.

Jerald Greenberg dan Tobert A. Baron dalam Wibowo (2007: 379), menyatakan bahwa motivasi merupakan serangkaian proses yang membangkitkan (arause), mengarahkan (direct), dan menjaga (maintain) perilaku manusia menuju pada pencapaian. Membangkitkan berkaitan dengan dorongan atau energi dibelakang tindakan. Motivasi juga berkepentingan dengan pilihan yang dilakukan manusia dan arah perilaku mereka. Sedangkan perilaku menjaga atau memelihara berapa lama orang akan terus berusaha untuk mencapai tujuan.

Robbin dan Judge (2008: 223), mengartikan motivasi (motivation) 
sebagai proses yang menjelaskan intensitas, arah, dan ketekunan seorang individu untuk mencapai tujuanya. Sopiah (2007: 170) mendefinisikan motivasi sebagai keadaan dimana usaha dan kemauan keras seseorang diarahkan kepada pencapaian hasil-hasil atau tujuan tertentu.

Dari definisi peneliti di atas dapat diambil kesimpulan bahwa pada dasarnya motivasi merupakan kebutuhan dan keinginan pribadi seseorang yang berpengaruh kepada perilaku dalam menjalankan tugasnya. Dengan begitu dapat diartikan bahwa motivasi dipengaruhi oleh keinginan, tujuan, kebutuhan dan dorongan-dorongan tertentu dalam melaksanakan tugas demi mengharapkan imbalan yang bersifat material maupun non material.

\section{Religiusit as}

Agama merupakan sesuatu yang tidak dapat terpisahkan dari kehidupan manusia. Muhaimin, Mujib, dan Mudzakkir (2005: 35) mengartikan agama (religi atau din) sebagai jalan hidup yang harus ditempuh oleh manusia dalam kehidupan didunia, sehingga mendatangkan kehidupan yang teratur, aman, tentram, dan sejahtera. Jalan hidup tersebut berisi aturan-aturan, nilai dan norma-norma yang mengatur kehidupan manusia yang tumbuh dan berkembang bersamaan dengan tumbuh dan berkembanganya kehidupan manusia, masyarakat dan budaya yang membentuk suatu sistem kehidupan keagamaan, sosial, kebudayaan.

Glock \& Stark (1996) sebagai ahli psikologi agama, memberikan definisi agama sebagai sistem simbol, sistem keyakinan, sistem nilai, dan sistem perilaku yang terlembagakan, yang semuanya itu berpusat pada persoalan-persoalan yang dihayati sebagai yang paling maknawi (ultimate meaning) (Ancok \& Suroso, 2008: 76).

Dari istilah agama inilah muncul religiusitas, seperti penjelasan Samsari (2004: 11) bahwa religiusitas merupakan tingkat keimanan seseorang dalam menghayati dan mengamalkan ajaran-ajaran agama yang dianutnya. Religiusitas secara umum dihubungkan dengan kognisi (pengetahuan dan keyakinan beragama) yang mempengaruhi, apa yang dilakukan dengan kelekatan emosional atau perasaan emosional tentang agama, dan atau perilaku, seperti kehadiran ditempat peribadatan, membaca kitab suci, dan berdoa (Elci, 2007 dalam Sulistyo, 2011: 254). Religiusitas lebih mengarah 
pada kualitas penghayatan dan sikap hidup seseorang berdasarkan nilainilai keagamaan yang diyakininya dan lebih menekankan pada substansi nilai-nilai luhur keagamaan serta cenderung memalingkan diri dari formalisme keagamaan (Ghozali, 2002: 2).

\section{Fungsi dan dimensi religiusitas}

Dalam mempengaruhi aspek-aspek kehidupan, agama atau religiusitas memiliki beberapa fungsi, yang menurut (Ancok \& Suroso, 2008: 124) fungsi tersebut adalah:

1. Agama sebagai sumber ilmu dan sumber etika ilmu.

2. Agama sebagai alat justifikasi dan hipotesis.

3. Agama sebagai motivator

4. Agama menjalankan fungsi pengawasan sosial (penjaga moral)

Glock dan Stark (Rebertson, 1988) dalam Ancok \& Suroso (2008:

77) menerangkan tentang lima macam dimensi keagamaan, yaitu:

1. Dimensi keyakinan (ideologis) atau akidah Islam

Dalam islam, keyakinan sejajar dengan akidah yang menunjuk pada seberapa tingkat keyakinan seorang muslim dalam melaksanakan kegiatan ritual sesuai yang dianjurkan oleh agama.

2. Dimensi peribadatan (ritualistik) atau syariah

Dimensi ini berisi tentang seberapa jauh tingkat ketaatan untuk menunjukkan komitmen terhadap agama yang dianut.

3. Dimensi penghayatan atau pengalaman (eksperiensial)

Dimensi ini berkaitan dengan pengamalan keagamaan, perasaanperasaan, persepsi-persepsi, dan sensasi-sensasi yang dialami seseorang dalam menjalankan agama yang dianut.

4. Dimensi pengetahuan agama (intelektual)

Dimensi ini mengacu pada pengatahuan seseorang mengenai ajaranajaran agamanya. Dalam praktik kehidupan, seseorang yang melaksanakan perintah dan menjauhi larangan agama akan memperoleh kesejahteraan lahir dan batin (dunia dan akhirat).

5. Dimensi pengamalan (konsekuensial) atau akhlak 
Dimensi ini membahas seberapa tingkatan seorang muslim dalam berperilaku sehingga dimotivasi oleh ajaran-ajaran agama, yang mencakup hubungan antara sesama manusia atau relasi antara individu dengan dunianya serta seberapa jauh seseorang dapat menerapkan ajaran agama dalam perilaku sehari-hari.

\section{Kepuasan Kerja}

Kepuasan kerja merupakan faktor yang dapat diwujudkan dalam suatu hasil namun tidak tampak dan tidak nyata yang mencakup sikap seseorang terhadap pekerjaanya. Bagaimana menumbuhkan perasaan senang terhadap pekerjaan dan tidak merasa terpaksa untuk bekerja, menjadi perhatian utama demi tercapainya kepuasan kerja yang akan berimbas pada produktifitas organisasi atau lembaga.

Wibowo (2007: 501) mengutarakan pendapat Greenberg dan baron (2003: 148) yang mendeskripsikan bahwa kepuasan kerja sebagai sikap positif atau negatif yang dilakukan individual terhadap pekerjaan mereka sedangkan Vechino (1995: 124), menyatakan kepuasan kerja sebagai pemikiran, perasaan, dan kecenderungan tindakan seseorang, yang merupakan sikap seseorang terhadap pekerjaan.

Robbin dan Judge (2008:40) mendefinisikan kepuasan kerja (job satisfaction) sebagai perasaan positif tentang pekerjaan seseorang yang merupakan hasil dari evaluasi karakteristiknya dan lebih tertuju pada sikap dibandingkan perilaku. Senada dengan definisi tersebut, Robbins dan Coulter (2005: 52) menyatakan bahwa kepuasan kerja adalah semua sikap umum individual terhadap pekerjaanya.

Dalam penelitian Mustafa dan Lines kepuasan kerja didefinisikan sebagai:

"Job satisfaction as a pleasure or positive affective state that results from an individual's appraisal of his or her work experience. Many past studies found that managerial practices and behaviors are associated with employee satisfaction and other workplace outcomes 
(Locke, 1983; Bluestone \& Bluestone, 1994; Jackson, 1983; Peterson \& Hillkirk, 1991)”.

Berdasarkan beberapa pengertian kepuasan kerja di atas, maka dapat disimpulkan bahwa kepuasan kerja merupakan perasaan yang ada dalam diri pegawai berkaitan dengan pekerjaan dan balasan dari apa yang telah dikerjakan, tidak terlepas dari kondisi para pegawai itu sendiri.

\section{Keterkaitan antar variabel pengaruh kepemimpinan terhadap kepuasan kerja}

Perilaku pimpinan menjadi faktor penting bagi karyawan untuk menentukan kepuasan kerja. Dalam penelitian Voon, Loo, Ngui dan Ayob (2011: 29) pada organisasi pemerintah di Malaysia, menunjukkan adanya hubungan positif antara gaya kepemimpinan tranformasional terhadap kepuasan kerja karyawan. Lain halnya pada penelitian Brahmasari dan Suprayitno (2008: 133), membuktikan bahwa kepemimpinan mempunyai pengaruh negatif dan signifikan terhadap kepuasan kerja karyawan.

Penelitian Yun, Cox, Sims, dan Salam (2007: 187) membuktikan adanya pengaruh positif antara kepemimpinan transformasional dan kepuasan kerja, namun dalam penelitian ini, kepemimpinan transaksional memeberikan pengaruh negatif terhadap kepuasan kerja.

\section{Pengaruh motivasi terhadap kapuasan kerja}

Jerald Greenberg dan Tobert A. Baron dikutip dari Wibowo (2008: 379), menyatakan bahwa motivasi merupakan serangkaian proses yang membangkitkan (arause), mengarahkan (direct), dan menjaga (maintain) perilaku manusia menuju pada pencapaian.

Dalam buku Wibowo (2007: 506) mengemukakan bahwa terdapat hubungan positif dan signifikan antara motivasi dan kepuasan kerja. Dalam penelitian Brahmasari dan Suprayitno motivasi terbukti dapat mempengaruhi kepuasan kerja secara positif, namun tidak signifikan. Sedangkan dalam penelitian Gunawan pada Boby Lesmana Art Shop Gianyar Bali, membuktikan bahwa terdapat pengaruh positif dan signifikan antara 
kepemimpinan, motivasi dan komunikasi terhadap kepuasan kerja karywan baik pengaruh simultan maupun parsial, terkecuali komunikasi yang berpengaruh tidak signifikan terhadap kepuasan kerja karyawan.

Nalendra (2008: 42) dalam penelitianya juga menemukan pengaruh positif dan signifikan antara motivasi dengan kepuasan kerja. Sama halnya dengan penelitian Irawan (2011: 59), yang menemukan pengaruh positif dan signifikan antara motivasi dan kepuasan kerja karyawan pada PT. Levias Indonesia.

\section{Pengaruh religiusitas terhadap kepuasan kerja}

Dalam penelelitian Ghozali (2002: 10) menemukan adanya pengaruh antara religiusitas terhadap kepuasan kerja, produktivitas, dan komitmen organisasi. Penelitian Samsari (2004: 73) juga menemukan adanya pengaruh positif antara religiusitas dimensi belief terhadap keterlibatan kerja, religiusitas dimensi komitmen dan behaviour tidak mempunyai pengaruh positif terhadap keterlibatan kerja, sedangkan keterlibatan kerja dan komitmen organisasi mempunyai pengaruh positif terhadap kepuasan kerja. Dengan kata lain religiusitas dimensi belief berpengaruh positif secara tidak langsung terdahap kepuasan kerja.

\section{Kerangka penelitian}

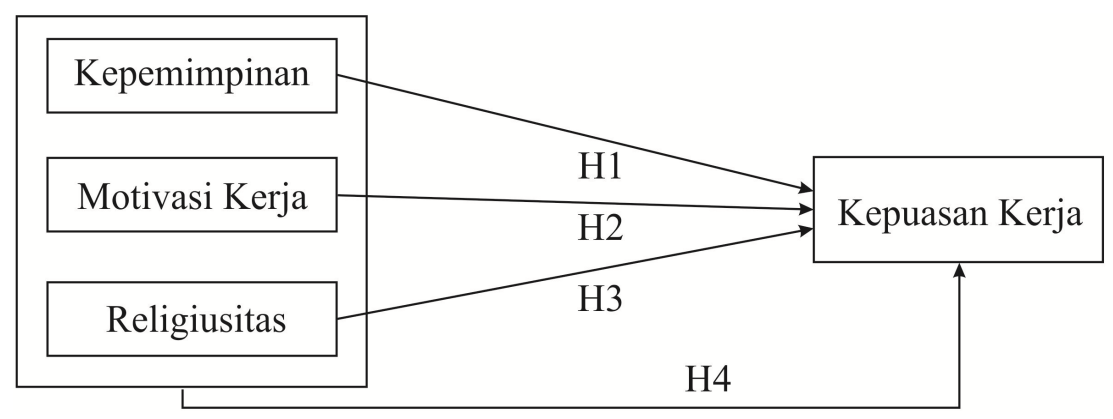

Gambar 2.2.

Kerangka Penelitian

Hubungan kepemimpinan, motivasi, dan religiusitas terhadap 
kepuasan kerja diteliti secara parsial dan secara simultan.

\section{Hipotesis}

Hipotesis merupakan pernyataan dugaan, suatu proposisi tentative (sementara) mengenai hubungan atau relasi antara dua atau lebih fenomen atau variabel (Sutama, 2011:19).

Berdasarkan uraian kerangka pemikiran di atas, maka penulis menarik hipotesis sebagai berikut:

H1. Terdapat pengaruh kepemimpinan terhadap kepuasan kerja karyawan di PT. Unza Vitalis Salatiga.

H2. Terdapat pengaruh motivasi kerja terhadap kepuasan kerja karyawan di PT. Unza Vitalis Salatiga.

H3. Terdapat pengaruh religiusitas terhadap kepuasan kerja karyawan di PT. Unza Vitalis Salatiga.

H4. Terdapat pengaruh kepemimpinan, motivasi kerja, dan religiusitas secara bersama-sama terhadap kepuasan kerja karyawan di PT. Unza Vitalis Salatiga.

H5. Kepemimpinan merupakan variable paling dominan dalam mempengaruhi kepuasan kerja karyawan PT. Unza Vitalis Salatiga.

\section{Metode Penelitian}

1. Jenis Penelitian

Menurut pendekatan analisis data yang akan digunakan, penelitian ini akan menggunakan metode kuantitatif. Dimana penulisakan berusaha menekankan analisisnya pada data-data yang diolah dengan metode statistic kemudian hasilnya akan disajikan secara sistematik, sehingga dapat lebih mudah untuk difahami dan disimpulkan, kemudian data hasil pengolahan statistic akan dijabarkan secara deskriptif.

2. Lokasi Penelitian

Dalam penelitian ini, penulis melakukan penelitian pada PT. Unza Vitalis 
Salatiga Indonesia dengan alamat J1. Soekarno-Hatta, Km 5,5, Dusun Brajan, RT 11/04, Kelurahan Noborejo, Kecamatan Argomulyo, Salatiga, Jawa Tengah Indonesia.

3. Populasi dan Sampel

Dalam penelitian ini, populasi yang digunakan penulis adalah seluruh karyawan PT. UnzaVitalis Salatiga yang berjumlah kurang lebih 250 orang. Menggunakan random sampling technique sehingga setiap anggota populasi mempunyai peluang yang sama untuk dipilih menjadi anggota sampel.

Menggunakan metode slovin, dengan tingkat kesalahan 8 persen, maka sampel ditentukan sebanyak 100 responden.

4. Teknik Pengumpulan Data

Teknik pengumpulan data yang akan digunakan dalam penelitian ini di antaranya: Pengumpulan data primer dilakukan dengan melakukan survey langsung ke PT. Unza Vitalis Salatiga sebagai objek penelitian. Data primer dalam penelitian ini akan diperoleh melalui angket (questionare). Dalam penelitian ini angket berisi tentang respon yang meliputi gambar anumum, perhatian dan pendapat responden terhadap pengaruh kepemimpinan, motivasi kerja, religiusitas dan kepuasan kerja pegawai di PT. Unza Vitalis Salatiga.

Data sekunder dapat diperoleh dari jurnal, majalah, buku, data statistic maupun dari internet.

5. Definisi Operasional

Agar konsep data dapat diteliti secara empiris, maka konsep di atas dioperasionalisasikan dengan cara mengubahnya menjadi variable atau sesuatu yang mempunyai nilai. Variabel tersebut meliputi kepemimpinan $(\mathrm{K})$, motivasikerja (M), danreligiusitas (R) sebagai variable bebas (independentvariable), sedangkan kepuasan kerja (Y) sebagai variable terikat (dependent variable).

6. Uji Instrumen Penelitian

Sebelum instrument di atas digunakan dalam penenilian, peneliti terlebih dahulu melakukan pengujian instrument tersebut supaya menghasilkan 
suatu penelitian yang akura tmenggunakan uji reliabilitas dan uji validitas.

7. Alat Analisis

Data yang diperoleh mengenai objek penelitian yang merupakan data kuantitatif output dari SPSS 20, kemudian dianalisis secara deskriptif.

Data akan diuji dengan uji kecocokan model yang meliputi uji T-tes, $\mathrm{UjiF}_{\text {test, }}$ dan Uji Koefisien Determinasi $\left(\mathrm{R}^{2}\right)$. Kemudian untuk menghindari gejala-gejala asumsi klasik, maka akan dilakukan pengujian multi collinearity, heteroscedasticity, normality, dan linearity.

\section{Uji Kecocokan Model}

a. Uji $t_{\text {test }}$

Uji ini digunakan untuk melihat signifikansi pengaruh variabel independen terhadap variabel dependen secara individu. Berikut merupakan tabel koefisien untuk melihat nilai t hitung yang akan dibandingkan dengan nilai t tabel.

Tabel 6

\section{Coefficients $^{\mathrm{a}}$}

\begin{tabular}{|c|c|c|c|c|c|}
\hline \multirow[t]{2}{*}{ Model } & \multicolumn{2}{|c|}{ Unstandardized Coefficients } & \multirow{2}{*}{$\begin{array}{c}\text { Standardized } \\
\text { Coefficients } \\
\text { Beta }\end{array}$} & \multirow[t]{2}{*}{$\mathrm{t}$} & \multirow[t]{2}{*}{ Sig. } \\
\hline & $\mathrm{B}$ & Std. Error & & & \\
\hline $\begin{array}{l}\text { (Constan } \\
\text { t) }\end{array}$ & $-44,504$ & 11,729 & & $-3,794$ &, 000 \\
\hline $\mathrm{K}$ & 290 & , 141 & , 166 & 2,057 &, 042 \\
\hline M & 1,070 & , 178 &, 505 & 6,017 &, 000 \\
\hline $\mathrm{R}$ & ,270 &, 065 & ,287 & 4,146 &, 000 \\
\hline
\end{tabular}

a. Dependent Variable: $\mathrm{Y}$

Sumber : Data Primer yang Diolah (2014)

Dari tabel coefficient, dapat dibuat model persamaan regresi sebagai berikut :

$$
\begin{aligned}
& Y=\beta_{0}+\beta_{1} K+\beta_{2} M+\beta_{3} R \\
& Y=-44,504+0,290 K+1,070 M+0,270 R
\end{aligned}
$$


Dimana :

$\mathrm{Y}=$ KepuasanKerja

$\mathrm{K}=$ Kepemimpinan

$\mathrm{M}=$ Motivasi

$\mathrm{R}=$ Religiusitas

\section{Artinya :}

1. K (kepemimpinan) berpengaruh positif terhadap kepuasan kerja (Y)

2. M (motivasi) berpengaruh positif terhadap kepuasan kerja (Y)

3. $\mathrm{R}$ (religiusitas) berpengaruh positif terhadap kepuasan kerja (Y)

Nilai constant $\left(\beta_{0}\right):-44,504$, diartikan bahwa ketika variabel $\mathrm{K}, \mathrm{M}$, dan $\mathrm{R}$ konstan atau tidak ada atau sebesar 0 , maka $\mathrm{Y}$ akan mengalami penurunan sebesar 44,504 satuan, dengan asumsi cateris paribus.

Nilai signifikansi variabel kepemimpinan (K) adalah sebesar 0,042 lebih kecil dari nilai $\beta(0.05)$, dengan kata lain terdapat pengaruh yang signifikan antara kepemimpinan terhadap kepuasan kerja.

Sedangkan nilai koevisien variabel kepemimpinan (K) sebesar 0,290, yang artinya setiap variabel kepemimpinan $(\mathrm{K})$ mengalami peningkatan 1 satuan angka sedangkan variabel lain ( $\mathrm{M}$ dan $\mathrm{R}$ ) konstan atau tidak ada atau sebesar 0, maka kepuasan kerja (Y) akan mengalami peningkatan sebesar 0,290 satuan, dengan asumsi cateris paribus.

Nilai signifikansi variabel motivasi (M) adalah sebesar 0,000 lebih kecil dari nilai $\beta(0.05)$ sehingga $\mathrm{H} 2$ diterima, dengan kata lain terdapat pengaruh yang signifikan antara motivasi terhadap kepuasan kerja.

Sedangkan nilai koevisien variabel motivasi (M) sebesar 1,070, yang artinya setiap variabel $\mathrm{M}$ mengalami peningkatan 1 satuan angka sedangkan variabel lain ( $\mathrm{K}$ dan $\mathrm{R}$ ) konstan atau tidak ada atau sebesar 0, maka kepuasan kerja (Y) akan mengalami peningkatan sebesar 1,070 satuan, dengan asumsi cateris paribus.

Berdasarkan pada tabel di atas nilai signifikansi variabel religiusitas (R) adalah sebesar 0,000 lebih kecil dari nilai á (0.05), dengan kata lain 
terdapat pengaruh yang signifikan antara religiusitas terhadap kepuasan kerja.

Sedangkan nilai koevisien variabel religiusitas (R) sebesar0,270, yang artinya setiap variabel $\mathrm{R}$ mengalami peningkatan 1 satuan angka sedangkan variabel lain ( $\mathrm{K}$ dan $\mathrm{M}$ ) konstan atau tidak ada atau sebesar 0, maka kepuasan kerja (Y) akan mengalami peningkatan sebesar 0.270 satuan, dengan asumsi cateris paribus.

b. Uji $F_{\text {test }}$

Uji $F$ test dilakukan untuk mengukur seberapa jauh variabel independen secara bersama-sama mempengaruhi variabel dependen. Uji $F$ test dapat dilihat pada tabel berikut :

Tabel 7.

ANOVA $^{\mathrm{a}}$

\begin{tabular}{|l|l|r|c|r|r|}
\hline Model & $\begin{array}{l}\text { Sum of } \\
\text { Squares }\end{array}$ & Df & $\begin{array}{c}\text { Mean } \\
\text { Square }\end{array}$ & F & Sig. \\
\hline $\begin{array}{l}\text { Regressio } \\
\mathrm{n}\end{array}$ & 22785,886 & 3 & 7595,295 & $\begin{array}{r}59,29 \\
2\end{array}$ & $\begin{array}{r}, 000 \\
\mathrm{~b}\end{array}$ \\
$\begin{array}{l}\text { Residual } \\
\text { Total }\end{array}$ & 12297,554 & 96 & 128,100 & & \\
\hline
\end{tabular}

a. Dependent Variable: Y

b. Predictors: (Constant), R, K, M

Sumber : Data Primer yang Diolah (2014)

Dengan melihat tabel di atas, nilai $\mathrm{F}$ hitung sebesar 59,292. F tabel dapat dicari dengan melihat kolom df, yaitu dengan df pembilang 3 dan $\mathrm{df}$ penyebut 96 sedangakan $\alpha$ : 5\%, maka nilai $F$ tabel adalah 2,699. Berdasarkan nilai $\mathrm{F}$ hitung dan $\mathrm{F}$ tabel, maka $\mathrm{F}$ hitung $>\mathrm{F}$ tabel, sehingga dapat diambil kesimpulan bahwa variabel independen secara bersama-sama mempengaruhi variabel dependen secara signifikan.

\section{c. Uji $R^{2}$ (Koefisien Determinasi)}

Koefisien determinasi menunjukkan sejauh mana kontribusi variabelvariabel independen $(\mathrm{K}, \mathrm{M}$, dan $\mathrm{R})$ terhadap variabel dependen $(\mathrm{Y})$. Nilai $\mathrm{R}^{2}$ dapat dilihat dalam tabel berikut : 
Tabel 4.8.

Model Summary

\begin{tabular}{|l|r|r|r|r|}
\hline $\begin{array}{l}\text { Mode } \\
1\end{array}$ & R & R Square & $\begin{array}{c}\text { Adjusted R } \\
\text { Square }\end{array}$ & $\begin{array}{r}\text { Std. Error of } \\
\text { the Estimate }\end{array}$ \\
\hline 1 &, $806^{\mathrm{a}}$ &, 649 &, 639 & 11,31811 \\
\hline
\end{tabular}

a. Predictors: (Constant), R, K, M

Sumber : Data Primer yang Diolah (2014)

Tabel di atas menjelaskan bahwa variasi variabel independen mampu menjelaskan variasi variabel dependen sebesar 63,9 \% sedangkan sisanya sebesar $36,1 \%$ dijelaskan variasi variabel lain diluar model.

\section{Pengujian Hipotesis}

a. Uji Hipotesis $1(\mathrm{H} 1)$

Dari hasil uji $t_{\text {test }}$ nilai t hitung varibel kepemimpinan sebesar 2,057 dengan taraf signifikansi 0,042 dan nilai $\beta_{1} \mathrm{~K}$ sebesar 0,290 . Dengan demikian maka dapat disimpulkan bahwa terdapat pengaruh yang positif dan signifikan antara varibel kepemimpinan terhadap kepuasan kerja. Dengan demikian dinyatakan terdapat pengaruh kepemimpinan terhadap kepuasan kerja PT. Unza Vitalis Salatiga sehingga hipotesis H1 diterima.

b. Uji Hipotesis $2(\mathrm{H} 2)$

Dari hasil uji $t_{\text {test }}$ nilai t hitung varibel motivasi kerja sebesar 6,017 dengan taraf signifikansi 0,000 dan nilai $\beta_{1} \mathrm{M}$ sebesar 1,070. Dengan demikian maka dapat disimpulkan bahwa terdapat pengaruh yang positif dan signifikan antara variabel motivasi kerja terhadap kepuasan kerja. Dengan demikian dinyatakan terdapat pengaruh motivasi kerja terhadap kepuasan kerja PT. Unza Vitalis Salatiga sehingga hipotesis H2 diterima.

c. Uji Hipotesis $3(\mathrm{H} 3)$

Dari hasil uji $\mathrm{t}_{\text {test }}$ nilai $\mathrm{t}$ hitung varibel religiusitas sebesar 4,146 dengan taraf signifikansi 0,000 dan nilai $\beta_{1} \mathrm{R}$ sebesar 0,270 . Dengan demikian maka dapat disimpulkan bahwa terdapat pengaruh yang positif dan signifikan antara varibel religiusitas terhadap kepuasan kerja. Dengan 
demikian dinyatakan terdapat pengaruh religiusitas terhadap kepuasan kerja PT. Unza Vitalis Salatiga sehingga hipotesis H3 diterima.

d. Uji Hipotesis $4(\mathrm{H} 4)$

Dari hasil uji $\mathrm{F}_{\text {test }}$ perbandingan nilai $\mathrm{F}$ hitung sebesar 59,292 dan $\mathrm{F}$ tabel sebesar 2,699 (F hitung > F tabel), sehingga dapat diambil kesimpulan bahwa variabel independen secara bersama-sama mempengaruhi variabel dependen secara signifikan. Dengan demikian maka H4 diterima.

e. Uji Hipotesis 5 (H5)

Dari hasil uji $\mathrm{t}_{\text {test }}$ nilai $\beta_{1} \mathrm{~K}, \beta_{2} \mathrm{M}$ dan $\beta_{3} \mathrm{R}$ sebesar 0,290, 1,070 dan 0,270. Dengan demikian maka dapat disimpulkan bahwa nilai koefisien variabel (M) lebih besar dari nilai koefisien variabel lain, sehingga variabel independen yang paling dominan mempengaruhi kepuasan kerja $(\mathrm{Y})$ adalah variabel motivasi kerja (M). Dengan demikian variabel paling dominan dalam mempengaruhi kepuasan kerja bukanlah kepemimpinan, namun motivasi kerja, sehingga hipotesis H5 ditolak.

Berdasarkan hasil pengujian statistik, terlihat bahwa variabel-variabel independen secara parsial dan simultan berpengaruh terhadap variabel dependen. Pengaruh dari ketiga variabel tersebut bersifat positif dan signifikan, dengan kata lain peningkatan kualitas kepemimpinan, motivasi kerja, dan religiusitas di PT. Unza Vitalis akan meningkatkan kepuasan kerja yang diperoleh oleh para karyawan. Hal tersebut sesuai dengan hipotesis yang diajukan serta hasil penelitian sebelumnya. Pengaruh variabel-variabel tersebut akan dijelaskan sebagai berikut :

\section{Pengaruh kepemimpinan terhadap kepuasan kerja}

Hasil pengujian hipotesis (H1) membuktikan terdapat pengaruh antara kepemimpinan terdadap kepuasan kerja. Hasil uji statistik yang telah dilakukan menunjukkan nilai t hitung variabel $\mathrm{K}$ sebesar 2,057 dengan taraf signifikansi sebesar 0,042 lebih kecil dari 0,05. Pengujian statistik ini membuktikan bahwa kepemimpinan berpengaruh positif dan signifikan terdahap kinerja karyawan dan dengan kata lain dinyatakan bahwa terdapat pengaruh yang positif dan signifikan antara kepemimpinan terhadap kepuasan kerja pada karyawan PT. Unza Vitalis Salatiga. Hasil ini mendukung penelitian sebelumnya yang dilakukan oleh Riyadi (2011:44) yang menemukan 
pengaruh signifikan antara gaya kepemimpinan dan motivasi kerja terhadap kinerja karyawan, Von, Lo, Ngui \& Ayob (2011:29) tentang kepemimpinan, kinerja dan kepuasan kerja karyawan, dan senada dengan penelitian Haerani \& taba (2010:15) yang menemukan pengaruh positif dan signifikan antara kepemimpinan terhadap kepuasan kerja karyawan.

\section{Pengaruh motivasi kerja terhadap kepuasan kerja}

Hasil pengujian hipotesis (H2) membuktikan terdapat pengaruh antara motivasi kerja terdadap kepuasan kerja. Hasil uji statistik menunjukkan nilai t hitung variabel $M$ sebesar 6,017 dengan taraf signifikansi sebesar 0,000 yang mana nilai itu lebih kecil dari 0,05 . Pengujian statistik ini membuktikan bahwa motivasi berpengaruh positif dan signifikan terdahap kinerja karyawan dan dengan kata lain dinyatakan bahwa terdapat pengaruh yang positif dan signifikan antara motivasi kerja terhadap kepuasan kerja pada karyawan PT. Unza Vitalis Salatiga. Hasil ini mendukung penelitian sebelumnya yang dilakukan oleh Haerani \& taba (2010:15), Brahmasari dan Suprayetno (2008:133), Indaraswari \& Djastuti (2010:21) serta penelitian Narendra (2008:42) yang membuktikan pengaruh positif dan signifikan antara motivasi terhadap kepuasan kerja karyawan.

\section{Pengaruh religiusitas terhadap kepuasan kerja}

Hasil pengujian hipotesis (H1) membuktikan terdapat pengaruh antara kepemimpinan terdadap kepuasan kerja. Hasil uji statistik menunjukkan nilai t hitung variabel $\mathrm{R}$ sebesar 4,146 dengan taraf signifikansi sebesar 0,000 yang mana nilai itu lebih kecil dari 0,05. Pengujian statistik ini membuktikan bahwa religiusitas berpengaruh positif dan signifikan terdahap kinerja karyawan dan dengan kata lain dinyatakan bahwa terdapat pengaruh yang positif dan signifikan antara religiusitas terhadap kepuasan kerja karyawan pada PT. Unza Vitalis Salatiga. Hasil ini mendukung penelitian sebelumnya yang dilakukan oleh Sulistyo (2011:266) yang menyatakan bahwa religiusitas sangat penting dalam meningkatkan outcomes organisasi, Samsari (2004:70) juga mengemukakan pengaruh positif antara religiusitas, terhadap keterlibatan kerja yang selanjutnya mempengaruhi kepuasan 
kerja dengan positif, serta penelitian yang dilakukan oleh Hong (2009:152) yang mengemukakan bahwa spiritualitas ditempat kerja memiliki pengaruh yang kuat terhadap kepuasan kerja.

\section{Kesimpulan}

Dengan begitu berdasarkan pembahasan analisis mengenai pengaruh kepemimpinan, motivasi kerja dan religiusitas terhadap kepuasan kerja pada PT. Unza Vitalis Salatiga, maka penelitian ini menyimpulkan empat hipotesis diterima dan satu ditolak. Dengan keterangan sebagai berikut :

a. Kepemimpinan berpengaruh positif dan signifikan terhadap kepuasan kerja karyawan PT. Unza Vitalis Salatiga.

b. Motivasi kerja berpengaruh positif dan signifikan terhadap kepuasan kerja karyawan PT. Unza Vitalis Salatiga.

c. Religiusitas berpengaruh positif dan signifikan terhadap kepuasan kerja karyawan PT. Unza Vitalis Salatiga.

d. Kepemimpinan, motivasi kerja dan religiusitas secara simultan mempengaruhi kepuasan kerja dengan positif dan signifikan pada PT. Unza Vitalis Salatiga.

e. Variabel paling dominan dalam mempengaruhi kepuasan kerja adalah motivasi kerja.

\section{Daftar pustaka}

Ancok, Djamaludin \& Suroso, Fuad Nashori. 2008. Psikologi Islami. Pustaka Pelajar. Yogyakarta.

As-Suwaidan, Dr.Thoriq Muhammad \& Basayrahil, Faisal Umar. 2005. Sukses Menjadi Pemimpin Islami, Jakarta: Maghfirah Pustaka.

Brahmasari, Ida Ayu \& Suprayitno, Agus. 2008. "Pengaruh Motivasi Kerja, Kepemimpinan dan Budaya Organisasi Terhadap Kepuasan Kerja Karyawan serta Dampaknya pada Kinerja Perusahaan (Studi kasus pada PT. Pei Hai International Wiratama Indonesia)". Jurnal Manajemen dan Kewirausahaan, Vol.10, No.2,pp.124-125.

Buhler, Patricia. 2001. Alpa Teach Yourself Management Skills dalam 24 
Jam (Tarjamahan). Jakarta: Prenada Media.

Ghozali, Imam. 2002. "PengaruhReligiositasTerhadapKomitmenOrganisasi, Keterlibatan Kerja, Kepuasan Kerjadan Produktivitas". Jurnal Bisnis Strategi, Vol.9/Juli/Th.VII/2002, Fakultas Ekonomi Universitas Diponegoro, Semarang.

Gustisyah, Raika. 2009. “Analisis Faktor-Faktor yang Mempengaruhi Motivasi Kerja Penyuluh Perindustrian Pada Kantor Dinas Perindustrian dan Perdagangan Kota Medan.” Tesis USU Dalam Medan.http://repository.usu.ac.id/bitstream/123456789/4294/1/ 09E01483.pdf, diakses pada hari Senin, 14-04-2014 15.33.

Hong, Joon Young. 2009. The Influence Of Perceifed Workplace Spirituality On Job Satisfaction, Intention To Leave, And Emotional Exhaustion Among Community Mental Health Center Workers In The State Of Kansas.University of Kansas.

Loganatan, Roland. 2013. The Influence Of Leadership Styles On Job Satisfaction At A Cellulose Pulp Mill In Kwazulu-Natal: A Case Study. Durban University.

Muhaimin. 2005. Kawasan Dan Wawasan Studi Islam. Jakarta: Prenada Media.'

Mustafa, Ghulam. \& Lines, Rune. 2014. "Influence Of Leadership On Job Satisfaction". Jurnal Of Leadership Studies. Vol. 7, Num. 4, University of Pheonix.

O'Hair, Dan. Friedrich, Gustav W. \& Dixon, Lynda Dee. 2009. Strategic Communication: In Business And The Professios, Edisi Keenam (Tarjamahan). Jakarta: Prenada Media.

Raharjo, Susilo Toto \& Nafisah, Durotun. 2006. “Analisis Pengaruh Gaya Kepemimpinan Terhadap Kepuasan Kerja, Komitemen Organisasi dan Kinerja Karyawan (Studi Empiris Pada Departemen Agama Kabupaten Kendal dan Departemen Agama Kota Semarang)". Jurnal Studi Manajemen \& Organisasi. Vol.3, No.2, p.69-81.

Riyadi, Slamet. 2011. "Pengaruh Kompensasi Finansial, Gaya Kepemimpinan, dan Motivasi Kerja Terhadap Kinerja Karyawan pada Perusahaan Manufaktur di Jawa Timur". Jurnal Manajemen Dan Kewirausahaan, Vol.13, No. 1,p. 40-45.

Robbins, Stephen P. \& Judge, Timothy A. 2008. Perilaku Organisasi Edisi 12. Salemba Empat. Jakarta.

Robbins, Stephen P. \& Coulter, Mary. 2005. Manajemen Edisi 8. PT Indeks. Jakarta.

Ross, Wanda. 2005. The Relationship Between Employee Motivation, Job 
Satisfaction And Corporate Culture. University Of South Africa.

Samsari, Agustinus. 2004. Pengaruh Religiositas Terhadap Keterlibatan Kerja, Komitmen Organisasi, Kepuasan Kerja, dan Produktivitas; Studi Empiris Pada Kantor Akuntan Publik di Semarang. Fakultas Ekonomi Universitas Katolik Soegijapranata, Semarang.

Siswanto \& Sucipto, Agus. 2008. Teori \& Perilaku Organisasi., Malang: UIN-Malang Press.

Sopiah. 2008. Perilaku Organisasional. Yogyakarta: Andi Offset.

Sulistyo, Heru, 2011. "Peran Nilai-Nilai Religiusitas Terhadap Kinerja Karyawan Dalam Organisasi". Media Riset \& Manajemen. Vol.11,No.3,pp.252-270.

Suryana, Nana. Haerani, Siti. \& Taba, M. Idrus. Pengaruh Kepemimpinan dan Motivasi Kerja Terhadap Kepuasan Kerja Karyawan dan Kinerja Perusahaan (Studi Kasus di Divisi Tambang PT. Inco Sorowako).

Sutama. 2011. Metode Penelitian Pendidikan Kuantitatif, Kualitatif, PTK, $R \& D$, Surakarta: Fairus Media.

Voon \& Lo \& Ngui \& Ayob. 2011. "The Influence of Leadership Styles on Employess' Job Satisfaction in Public Sector Organizations In Malaysia”. International Jurnal of Business, Management and Social Sciences. Vol.2, No.1, hal. 24-32.

Wibowo.2007. Manajemen Kinerja, Edisi Ketiga. Jakarta: Rajawali Press.

Yun, Soekhwa. Cox, Jonatan.\& Sims, Henry P. 2007. "Leadership and Teamwork: The Effect of Leadership and Job Satisfaction on Team Citizenship". International Jurnal of Leadership Studies, Vol. 2 Iss. 3, p. 171-193. Regent University. 